DOI: http://dx.doi.org/10.1590/fst.2014.0049

\title{
Mineral characterization of native fruits from the southern region of Brazil
}

\author{
Marina Couto PEREIRA ${ }^{1}$, Wiliam BOSCHETTI ${ }^{2}$, Roger RAMPAZZO², Paulo Gustavo CELSO²,
} Plinho Francisco HERTZ ${ }^{1}$, Alessandro de Oliveira RIOS ${ }^{1}$, Márcia VIZZOTTO ${ }^{3}$, Simone Hickmann FLORES ${ }^{1 *}$

\begin{abstract}
Although the greatest variety of Brazilian flora is in the Amazon region, the Southern region of Brazil also has an estimated number of at least 5,000 species of vascular native plants. These species have been neglected as potential food sources, remaining unknown and under-utilized and limiting the potential variety in the diet of Brazilians and other peoples. Therefore the aim of this study was to characterize the mineral composition and content present in seven native fruit species of Southern Brazil using inductively coupled plasma optical emission spectrometry (ICP-OES). The essential element concentrations in the fruit samples were higher or similar to the values reported for traditional fruits. The araticum-do-mato fruit samples had high concentrations of the elements $\mathrm{Ca}, \mathrm{K}$, and $\mathrm{Cu}$, and trace elements such as $\mathrm{Pb}$ and $\mathrm{Sr}$. Mandacaru-de-três-quinas had predominance of $\mathrm{Ba}, \mathrm{Bi}$, and $\mathrm{Ga}$, and the essential elements $\mathrm{Mg}$ and $\mathrm{Mn}$. Uvaia and guabiroba had the highest levels of $\mathrm{Al}$ and $\mathrm{Cr}$, but uvaia had high levels of Fe and $\mathrm{Zn}$. The pindo palm had high amounts of $\mathrm{Cd}$ and $\mathrm{Ni}$, and the yellow guava had high concentrations of $\mathrm{Na}$, while red guava had high levels of Co.
\end{abstract}

Keywords: mineral; fruits; ICP-OES.

\section{Introduction}

The mineral content of fruits can vary according to the plant, maturity, soil conditions, climate, and agricultural practices (Brack et al., 2007; Kinnup \& Barros, 2008). As an example, wild berries have significantly higher mineral levels than domesticated plants. In addition to the minerals, notconventional fruits and vegetables can be richer in fiber and compounds with antioxidant functions than conventional foods (Odhav et al., 2007; Pereira et al., 2012).

Minerals are essential regulators of physiological processes in humans. These elements are essential nutrients for the maintenance of health, but they cannot be synthesized by the body, and therefore, must be obtained through the diet. More than a third of all human proteins require metal ions to function. The absence of these ions can be harmful to human health (Bertini et al., 2001).

Minerals regulate the metabolism of various enzymes, maintain the acid-base balance and the osmotic pressure, facilitate the transfer of essential compounds through the membranes and, in some cases, are constituents of body tissues (Aberoumand \& Deokule, 2009).

The greatest variety of Brazilian flora is present in the Amazon region; however the Southern region of Brazil also has many species of vascular native plants. Araticum-do-mato (Rollinia sylvatica A. St. Hil.) is relatively common in the Atlantic Forest in the semi-deciduous forest, the forest of altitude, and in areas of restinga in the States of Pernambuco to Rio Grande do Sul, Minas Gerais, Goiás, and Mato Grosso do Sul. Red and yellow guava (Psidium cattleyanum Sabine) are widely grown in domestic orchards in the Southern region of Brazil, and are also common in the coastal restingas of the Atlantic Forest. Pindo palm fruit (Butia capitata ( Mart.) Becc.) is a noncultivated species native of Paraguay, Argentina, Uruguay, and Brazil; it can be found from Minas Gerais to Rio Grande do Sul (Lorenzi et al., 2006).

Guabiroba (Campomanesia xantocarpa O. Berg) is grown mainly in the South and Southeast of the Brazil, from Minas Gerais and Mato Grosso do Sul up to Rio Grande do Sul in almost all forests in these regions. Uvaia (Eugenia pyriformis Cambess) is widely cultivated throughout Brazil and is found from Sao Paulo to Rio Grande do Sul. Mandacaru-de-trêsquinas (Cereus hildmannianus K. Schum.) occurs in all forest types in the state of Rio Grande do Sul (Lorenzi et al., 2006; Sobral et al., 2006).

The aim of this study was to characterize the mineral composition and content in seven native fruit species of Southern Brazil using inductively coupled plasma optical emission spectrometry (ICP-OES) to compare the values obtained with values reported for conventional species.

\section{Materials and methods}

\subsection{Raw materials}

Araticum-do-mato (Rollinia sylvatica A. St. Hil.) (ICN 89236), red and yellow guava (Psidium cattleyanum Sabine) (ICN 119753), pindo palm fruit (Butia capitata (Mart.) Becc.) (ICN 34139), guabiroba (Campomanesia xanthocarpa O. Berg) (ICN 28811), uvaia (Eugenia pyriformis Cambess) (ICN 122770), and mandacaru-de-três-quinas (Cereus

\footnotetext{
Received 16 Dec., 2013

Accepted 19 Feb., 2014 (006257)

${ }^{1}$ Instituto de Ciência e Tecnologia de Alimentos, Universidade Federal do Rio Grande do Sul - UFRGS, Porto Alegre, RS, Brazil, e-mail: simone.flores@ufrgs.br

${ }^{2}$ Laboratório Nacional Agropecuário, Ministério da Agricultura, Pecuária e Abastecimento, Porto Alegre, RS, Brazil

${ }^{3}$ Embrapa Clima Temperado, Pelotas, RS, Brazil

${ }^{*}$ Corresponding author
} 
hildmannianus K. Schum.) (ICN 115413) clasdodios were used. The fruits were harvested from the native fruit collection of the Embrapa Temperate Climate Station (Pelotas/RS/Brazil), with the exception of the mandacaru-de-três-quinas, which came from the city of Barra do Ribeiro (RS/Brazil). The fruits were incorporated in the Institute of Natural Science (ICN) Herbarium of Federal University of Rio Grande do Sul (UFRGS). The analyses were performed using the edible portion of the fruits, (i.e., guava and guabiroba samples included the skin, pulp, and seeds; uvaia and pindo palm samples included both skin and pulp; araticum-do-mato and mandacaru-de-três-quinas samples included the pulp only).

The samples were collected at the stage of full maturity, frozen $\left(-20^{\circ} \mathrm{C}\right)$, and subsequently lyophilized (Lyophilizer L101, São Carlos, SP, Brazil).

\subsection{Sample preparation}

The digestion and the mineral determinations were performed at the National Laboratory Livestock Production (LANAGRO/RS) using the Altundag \& Tuzen (2011) method with minor modifications. The freeze-dried fruits $(500 \mathrm{mg}$ ) were transferred to decontaminated quartz tubes containing $1 \mathrm{~mL}$ of redistilled nitric acid (Merck), $2 \mathrm{~mL}$ of hydrogen peroxide (Merck), and $7 \mathrm{~mL}$ of ultra-pure water (conductivity $0.07 \mu \mathrm{S}$ ). After digestion, the solution was diluted and calibrated with ultra-pure water in a $25 \mathrm{~mL}$ volumetric flask. The digestion was performed in triplicate for each fruit and for the certified reference material (CRM).

\subsection{Microwave digestion}

The digestions were performed in a microwave oven (Anton Paar Multiwave 3000 - Perkin Elmer) equipped with a XQ80rotor with a capacity for 8 quartz tubes. The operating conditions were identical for the fruit samples and for the CRM (Table 1).

\subsection{Minerals analysis by USN-ICP-OES}

The minerals analyses were performed by inductively coupled plasma optical emission spectrometry (ICP-OES) (Varian-model View-MPX CCD) equipped with an ultrasonic nebulizer (Cetac model U5000TA+). All fruit samples were analyzed in quintuplicate assays. The operating conditions are presented in Table 2. The equipment calibrations were performed using dilutions of the standard elemental solutions at $1000 \mathrm{mg} / \mathrm{L}$ (Merck) containing the following minerals: Ag (Silver), Al (Aluminum), B (Boron), Ba (Barium), Bi (Bismuth), Ca (Calcium), Cd (Cadmium), Co (Cobalt), Cr (Chromium), Cu (Copper), Fe (Iron), Ga (Gallium), In (Indium), K (Potassium), Li (Lithium), Mg (Magnesium), Mn (Manganese), Na (Sodium), $\mathrm{Ni}$ (Nickel), $\mathrm{Pb}$ (Lead), Sr (Strontium), Ti (Titanium), and Zn (Zinc).

Calibration curves were constructed from 10 to $100 \mu \mathrm{g} \cdot \mathrm{kg}^{-1}$ for the trace elements, 100 to $1000 \mu \mathrm{g} . \mathrm{kg}^{-1}$ for the microelements, and from 1 to $500 \mathrm{mg} \cdot \mathrm{kg}^{-1}$ for the macroelements.
The method accuracy was checked using a certified reference material of peach leaves (NIST 1567) characterized with the following components: $\mathrm{Al}=92.05 \%, \mathrm{Ba}=71.78 \%$, $\mathrm{Cd}=1326.92 \%, \mathrm{Cu}=943.11 \%, \mathrm{Fe}=72.52 \%, \mathrm{~Pb}=79.29 \%$, $\mathrm{Mn}=81.95 \%, \mathrm{Ni}=648.82 \%, \mathrm{Sr}=85.21 \%$, and $\mathrm{Zn}=79.62 \%$.

Table 3 shows the wavelengths used for each mineral analyzed as well as the limit of detection (LOD) and quantification (LOQ).

\subsection{Statistical analyses}

The data were analyzed by ANOVA and Tukey's means comparison test at a significance level of $5 \%$, followed by a Principal Component Analysis (PCA) using the software Statistica 10.0.

\section{Results and discussion}

PCA is a statistical technique used to reduce the dimensionality of a data set containing a large number of inter-related variables. The analysis is performed to maintain the maximum variance present in the data. This reduction produces a new reduced and un-correlated set of variables, called principal components. These components are then chosen to ensure that the former retain the greater part of the variance present in the original variables.

The seven native fruits were evaluated for the presence and content of eighteen minerals. Both indium (In) and titanium

Table 1. Operating conditions for the microwave digestion of the fruit samples.

\begin{tabular}{lc}
\hline \multicolumn{1}{c}{ Parameters } \\
\hline Potency & $1000 \mathrm{~W}$ \\
Pressure limit & $80 \mathrm{bar}$ \\
Rate of pressure increase & $0.8 \mathrm{bar} / \mathrm{s}$ \\
Temperature limit & $280^{\circ} \mathrm{C}$ \\
Irradiation limit & $250{ }^{\circ} \mathrm{C}$ \\
Exhaust velocity & Level 1 \\
Cooling time & $15 \mathrm{~min}$ \\
Ramp & $10 \mathrm{~min}$ \\
Hold & $25 \mathrm{~min}$ \\
\hline
\end{tabular}

Table 2. Operating conditions for the mineral determination of minerals in the ICP and the ultrasonic nebulizer.

\begin{tabular}{lc}
\hline \multicolumn{1}{c}{ Parameters } \\
\hline Potency & $1200 \mathrm{~W}$ \\
Plasma flow & $12 \mathrm{~L} / \mathrm{min}$ \\
Flow of the auxiliary gas (argon) & $1.5 \mathrm{~L} / \mathrm{min}$ \\
Height of reading & $4 \mathrm{~mm}$ \\
Reading time of replications & $10 \mathrm{~s}$ \\
Pump speed & $25 \mathrm{rpm}$ \\
Cleaning time & $20 \mathrm{~s}$ \\
Pressure of nebulizer & $200 \mathrm{kPa}$ \\
Heating stage & $140{ }^{\circ} \mathrm{C}$ \\
Cooling stage & $3{ }^{\circ} \mathrm{C}$ \\
\hline
\end{tabular}


Table 3. Wavelength, limit of detection (LOD), and quantification (LOQ) used in the mineral analysis of the Brazilian fruits.

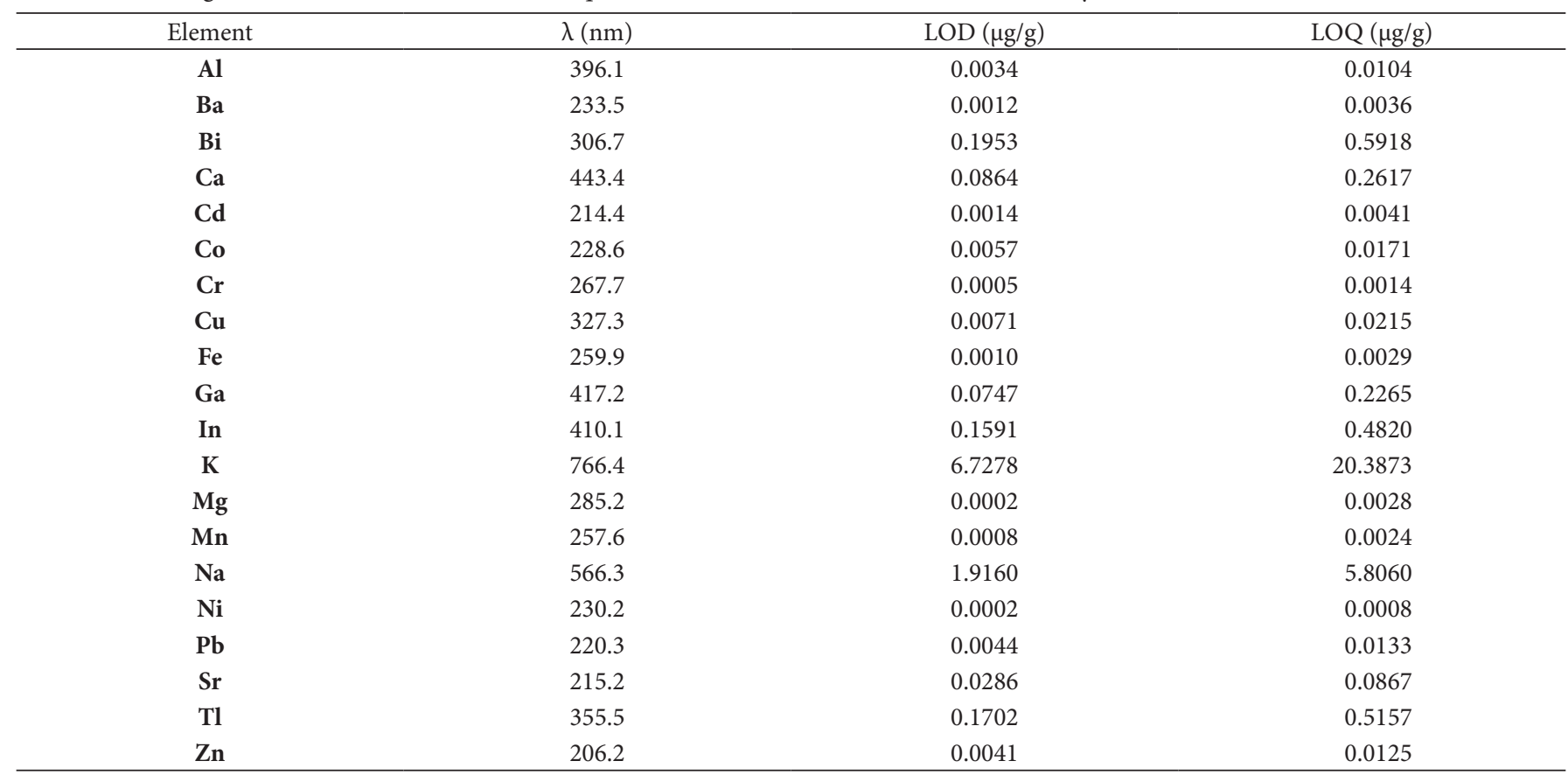

(Ti) (Table 4) were not detected in the samples. During the analysis, the main component 1 (PC1) was determined to be primarily related to the minerals $\mathrm{Al}, \mathrm{Ba}, \mathrm{Bi}, \mathrm{Ga}, \mathrm{Mg}$, and $\mathrm{Mn}$, the principal component 2 (PC2) related to $\mathrm{Cu}, \mathrm{Fe}, \mathrm{Sr}$, and $\mathrm{Zn}$, and the principal component 3 (PC3) related to Co (Table 5). In this analysis, $77.17 \%$ of the total variance of the data was accounted for with the significant contributions of $31.43 \%$ for the first, $26.45 \%$ for the second, and $19.29 \%$ for the third principal components (Table 5).

The minerals $\mathrm{Cd}, \mathrm{Na}$, and Ca were explained by the fourth, fifth, and sixth main components, respectively. $\mathrm{Cr}, \mathrm{K}$, and $\mathrm{Pb}$ did not significantly contribute to differentiation analysis of the fruit samples.

Guabiroba, pindo palm, and uvaia contained high levels of $\mathrm{Zn}, \mathrm{Cr}, \mathrm{Ni}, \mathrm{Al}$, and $\mathrm{Fe}$ with minor amounts of $\mathrm{Mg}$ and $\mathrm{Ba}$ (Figures 1a, b). For both $\mathrm{Al}$ and $\mathrm{Cr}$, guabiroba and uvaia were considered statistically equivalent, with values that were significantly higher than those of the other fruit samples (Table 4). Compared with the other fruits, both Uvaia and pindo palm contained the largest concentrations of $\mathrm{Zn}$ and Ni. Pindo palm and araticum-do-mato showed the highest concentration of Cd compared with that of the other studied fruits.

Both $\mathrm{Al}$ and $\mathrm{Ni}$ are considered toxic to humans. An excessive amount of Al may be related to a variety of neurodevelopmental disorders, including encephalopathy, Parkinson's disease, and Alzheimer's disease (Sobral et al., 2006). Nickel has also been reported to be a carcinogenic element (Cassaret \& Doull's, 1996). Our study determined that the concentrations of these minerals in these fruits were within the acceptable range since the daily recommended dose should not exceed $13000 \mu \mathrm{g}$ for Al (World Health Organization, 1996) and $1000 \mu \mathrm{g}$ for $\mathrm{Ni}$ (Padovani et al., 2006).
Several studies have determined that the levels of nickel range from $0.61 \mu \mathrm{g} . \mathrm{g}^{-1}$ in black plum to $2.54 \mu \mathrm{g} . \mathrm{g}^{-1}$ in fig fruit. Altundag \& Tuzen (2011) and 2.30-5.83 $\mu \mathrm{g} \cdot \mathrm{g}^{-1}$ in species of apricot originating Turkey (Saracoglu et al., 2009), which is consistent with the results found in the present study. $\mathrm{Cr}$ is an essential mineral for human metabolism. Depending on its structural form, this mineral can be toxic and carcinogenic. The levels found in this study exceeded the United States Food and Drug Administration (FDA) recommended dosage of 0.12 $\mu \mathrm{g} \cdot \mathrm{g}^{-1}$ (Haider et al., 2004). In contrast, the recommendations of the Dietary Reference Intakes (Institute of Medicine, 2005), which suggest a range of 25 to $35 \mu \mathrm{g} \mathrm{Cr} /$ day for men and 20 to $25 \mu \mathrm{g} \mathrm{Cr} /$ day for women, depending on the age, indicate that the Cr levels determined for these fruits would be within the acceptable range.

The reported chromium levels in multiple fruits include $0.011 \mu \mathrm{g} / \mathrm{g}$ in apricot (Saracoglu et al., 2009), 0.8-6.17 $\mu \mathrm{g} . \mathrm{g}^{-1}$ in different dried fruits from Turkey (black grape, mulberry, yellow and black plum, apricot, and rose hip), 0.58-2.30 in white mulberry - $2.30 \mu \mathrm{g} . \mathrm{g}^{-1}$ in apricot (Altundag \& Tuzen, 2011) and $2.41 \mu \mathrm{g} \cdot \mathrm{g}^{-1}$ in strawberry (Özcan \& Hacıseferoğulları, 2007).

As an essential trace element, $\mathrm{Zn}$ is important for both reproduction and growth, acting as an activator in a series of metabolic reactions catalyzed by enzymes (Bertini et al., 2001). The presence of this mineral in uvaia fruit is impressive. While leafy vegetables and fruits are considered modest sources of this element (Institute of Medicine, 2005), the $\mathrm{Zn}$ content in uvaia was determined to be significantly higher than that of the multiple fruits, cereals, and vegetables studied by Altundag \& Tuzen (2011) (2.85 in grape and $6.23 \mu \mathrm{g} \cdot \mathrm{g}^{-1}$ in apricot), Saracoglu et al. (2009) (2.96-12.01 $\left.\mu \mathrm{g}^{-\mathrm{g}^{-1}}\right)$ in species of apricot and Ekholm et al. (2007) (1 in wheat bread and $8.9 \mu \mathrm{g} \cdot \mathrm{g}^{-1}$ in 
Pereira et al.

Table 4. Mineral levels ( $\left.\mu \mathrm{g} \cdot \mathrm{g}^{-1}\right)$ in seven fruits native to the South of Brazil.

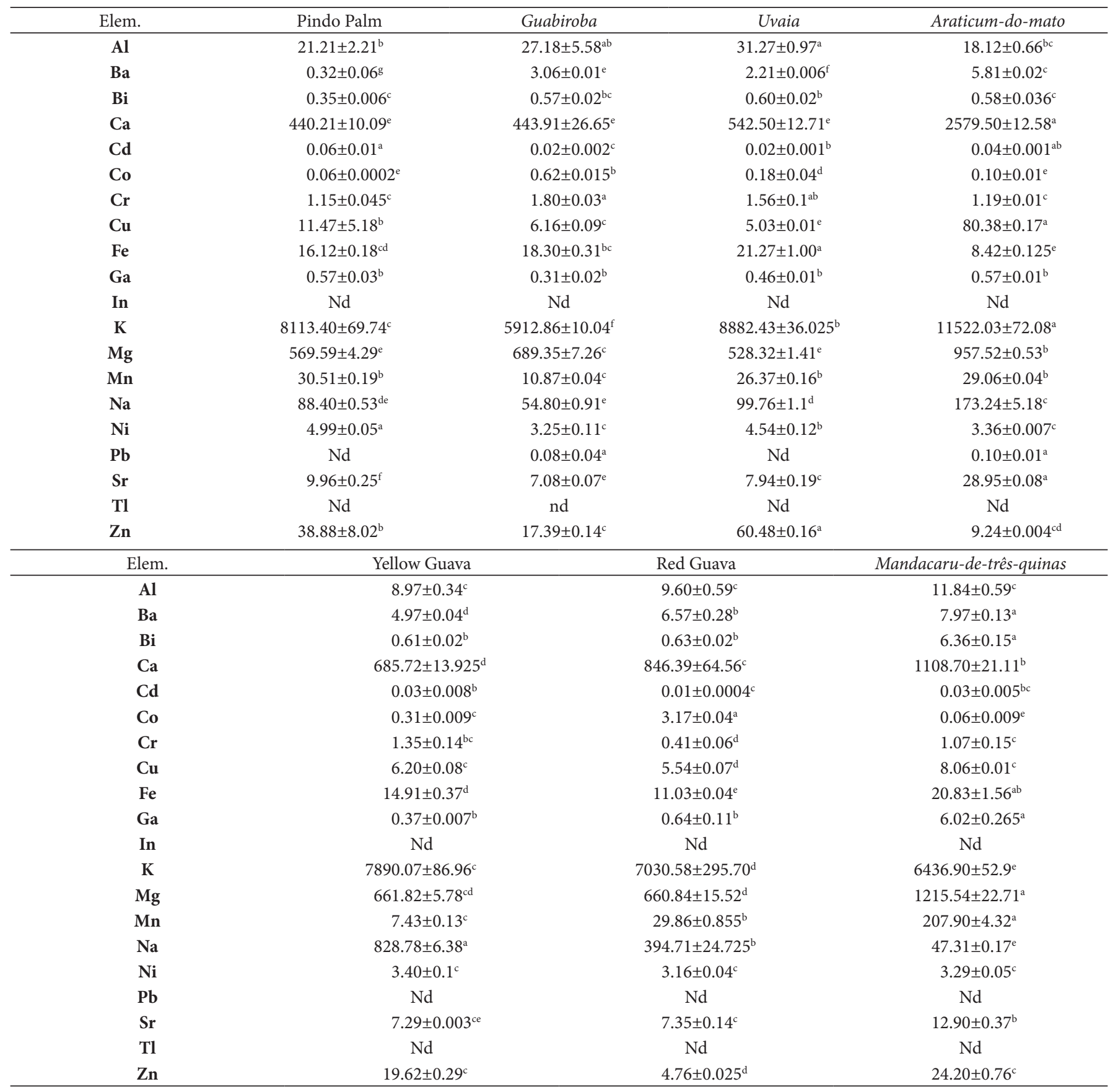

wheat bran), and the results that were similar to those reported by Sattar et al. (1989) (64.2-65.8 $\left.\mu \mathrm{g}^{-\mathrm{g}^{-1}}\right)$ in mixed spices.

Red Guava was characterized by high concentrations of $\mathrm{Ba}$, $\mathrm{Co}$, and $\mathrm{Na}$ and small amounts of $\mathrm{Zn}, \mathrm{Ni}$, and $\mathrm{Al}$ (Figures $\mathrm{1a}, \mathrm{b}$ ). The red guava had a higher content of Co compared to the other fruits (Table 4).

Considered to be an essential element for human beings, Co is an essential part of vitamin B12 (cyanocobalamin), and its deficiency can cause pernicious anemia. Since the human body is unable to synthesize vitamins, the ingestion of foods containing these compounds is essential. The recommended daily intake of vitamin B12 is $2.4 \mu \mathrm{g}$, containing approximately $0.1 \mu \mathrm{g}$ of cobalt. By increasing the production of red blood cells, this compound can prevent or treat anemia, as well as improve the absorption of iron by the body. On the other hand, exposure to high doses can cause toxic effects (Agency for Toxic Substances and Disease Registry, 2001).

Our analysis determined that red guava proved to be a good source of Co compared to the contents found in cereals, vegetables, and fruits by Ekholm et al. (2007), with values ranging from $<0.01$ to $0.18 \mu \mathrm{g} \cdot \mathrm{g}^{-1}$. 
Table 5. Variance, eigenvalues, and loadings of the minerals analyzed in seven fruits native to Brazil.

\begin{tabular}{|c|c|c|c|}
\hline Parameters & PC1 & PC2 & PC3 \\
\hline Percentage of variance & $31.43 \%$ & $26.45 \%$ & $19.29 \%$ \\
\hline Percentage of variance cumulative & $31.43 \%$ & $57.88 \%$ & $77.17 \%$ \\
\hline Eigenvalue & 5.67 & 4.76 & 3.47 \\
\hline Eigenvalue cumulative & 5.67 & 10.42 & 57.88 \\
\hline Minerals & & Loadings & \\
\hline $\mathrm{Al}$ & 0.718349 & 0.438077 & 0.238158 \\
\hline $\mathbf{B a}$ & -0.849032 & -0.382346 & 0.147661 \\
\hline $\mathbf{B i}$ & -0.804907 & 0.371316 & 0.457746 \\
\hline $\mathrm{Ca}$ & 0.439645 & 0.212220 & 0.311071 \\
\hline Cd & 0.402715 & -0.053479 & 0.423175 \\
\hline Co & -0.313148 & -0.347495 & -0.713690 \\
\hline $\mathrm{Cr}$ & 0.499800 & 0.387805 & 0.296672 \\
\hline $\mathrm{Cu}$ & 0.217371 & -0.730023 & 0.641758 \\
\hline $\mathrm{Fe}$ & -0.072365 & 0.967317 & 0.090959 \\
\hline Ga & -0.796876 & 0.363382 & 0.466599 \\
\hline $\mathbf{K}$ & 0.513809 & -0.528616 & 0.479177 \\
\hline $\mathrm{Mg}$ & -0.724285 & -0.143978 & 0.671401 \\
\hline Mn & -0.768666 & 0.365029 & 0.492999 \\
\hline $\mathrm{Na}$ & -0.110260 & -0.373967 & -0.568506 \\
\hline $\mathrm{Ni}$ & 0.656841 & 0.516083 & 0.061182 \\
\hline $\mathbf{P b}$ & 0.261301 & -0.580624 & 0.476539 \\
\hline $\mathrm{Sr}$ & 0.489482 & -0.757213 & 0.420168 \\
\hline $\mathrm{Zn}$ & 0.501653 & 0.784329 & 0.136876 \\
\hline
\end{tabular}

Altundag \& Tuzen (2011) analyzed the mineral content in dry fruits, including black plums (Prunus domestica L.), figs (Ficus carica L.), mulberries (Morus alba L.), grapes (Vitis vinifera L.), yellow plums (Prunus armeniaca L.), and apples (Malus domestica) and found values of cobalt ranging between 0.25 and $1.09 \mu \mathrm{g} . \mathrm{g}^{-1}$. Saracoglu et al. (2009) found values between $0.2-1.78 \mu \mathrm{g} . \mathrm{g}^{-1}$ in dried apricots originating in Turkey.

As determined in our study, yellow guava also had a higher amount of cobalt compared to the fruits studied, but this value is quite smaller than those of the fruits from Turkey, including apples (35.24-39.9 $\left.\mu \mathrm{g} \cdot \mathrm{g}^{-1}\right)$, plums $\left(45.32 \mu \mathrm{g} \cdot \mathrm{g}^{-1}\right)$, cornelians $\left(32.45-41.03 \mu \mathrm{g} . \mathrm{g}^{-1}\right)$, rosas $\left(27.75-41.20 \mu \mathrm{g} \cdot \mathrm{g}^{-1}\right)$ (Hamurcu et al., 2010), and strawberries (701.26 $\mu \mathrm{g} . \mathrm{g}^{-1}$ ) (Özcan \& Hacıseferoğulları, 2007).

Mandacaru-de-três-quinas was characterized by high concentrations of, $\mathrm{Ba}, \mathrm{Bi}, \mathrm{Ga}, \mathrm{Fe}, \mathrm{Mg}$, and $\mathrm{Mn}$ (Figures 1a-d). Compared with the other fruits, these elements were significantly different, except for the iron content, which was considered equivalent to the values found in uvaia. The function of $\mathrm{Ga}$ and $\mathrm{Bi}$ in the human body remains unknown. In contrast, $\mathrm{Mn}$ is an element of vital importance, contributing to structural components and the activation of several enzymes (Altundag \& Tuzen, 2011). The recommended daily dietary intake of $\mathrm{Mn}$ is $1.2 \mathrm{mg}$ for children 1-3 years old, and 1.8-2.3 $\mathrm{mg}$ for female and male adults. Values are lower for infants and higher for pregnant or lactating women, according to ATSDR (Agency for Toxic Substances and Disease Registry, 2008).

Our analysis suggested that these fruits can contribute to achieving these recommended values, especially the mandacaru-de-três-quinas, which showed higher values than those reported for multiple fruits studied by Altundag \& Tuzen

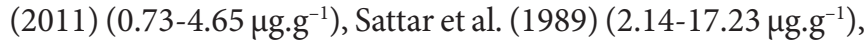
Duran et al. (2008) 4.74-25.5 $\mu \mathrm{g}^{-g^{-1}}$, with values that were similar to lingonberries $\left(175 \mu \mathrm{g} \cdot \mathrm{g}^{-1}\right)$, cranberries $\left(184 \mu \mathrm{g} \cdot \mathrm{g}^{-1}\right)$, and bilberries (289 $\left.\mu \mathrm{g} . \mathrm{g}^{-1}\right)$ (Ekholm et al., 2007).

Iron is a widely studied microelement and one of the most cited as an important nutrient. The recommended daily intake is approximately $10 \mathrm{mg}$ of iron for men and $20 \mathrm{mg}$ for women (World Health Organization, 1996). An essential element, iron operates as a component of hemoglobin, myoglobin, and cytochrome as well as a component of several enzymatic systems, playing an essential role in oxygen transport and cellular respiration (Aberoumand \& Deokule, 2009; Saracoglu et al., 2009).

Uvaia and mandacaru-de-três-quinas had higher content of iron than that of traditional fruits, including strawberries (12.15 $\mu \mathrm{g} . \mathrm{g}^{-1}$ ) (Ekholm et al., 2007), apples $\left(11 \mu \mathrm{g} \cdot \mathrm{g}^{-1}\right)$, and oranges $\left(11 \mu \mathrm{g} \cdot \mathrm{g}^{-1}\right)$, with similar values to those reported for some other fruits such as lingonberries $\left(17 \mu \mathrm{g} \cdot \mathrm{g}^{-1}\right)$, sea buckthorn $\left(22 \mu \mathrm{g} . \mathrm{g}^{-1}\right)$, and peaches $\left(23 \mu \mathrm{g} \cdot \mathrm{g}^{-1}\right)$ (Ekholm et al., 2007).

Both $\mathrm{Mg}$ and $\mathrm{Ba}$ have been reported to be the predominate minerals in guavas. In contrast, our analysis suggested that the mandacaru-de-três-quinas had the highest content of these two minerals among the fruits studied (Table 5).

Both $\mathrm{Mg}$ and $\mathrm{Ca}$ contribute to the formation of bones, teeth, and tissue helping the growth and maintenance of 

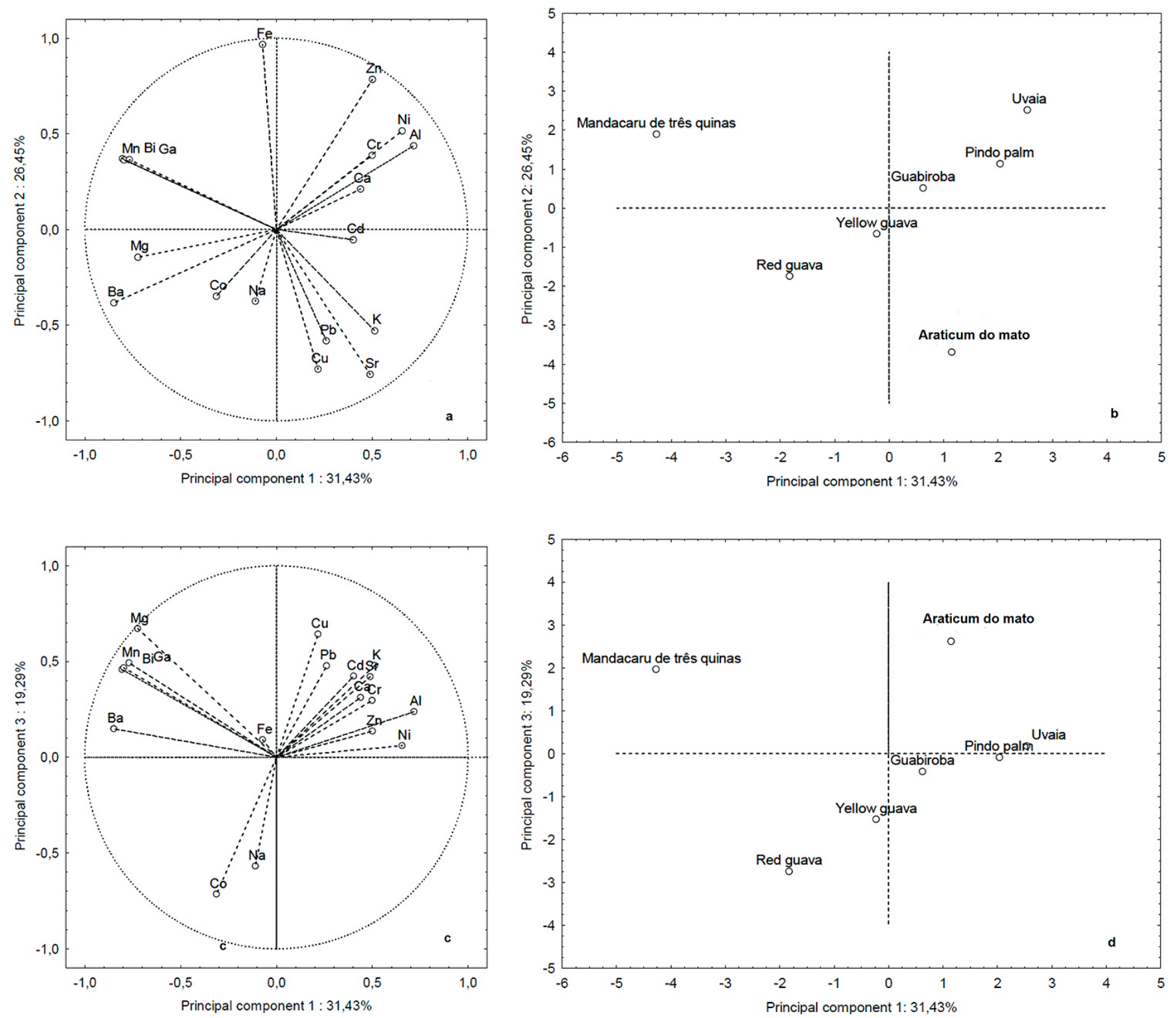

Figure 1. Principal component analysis of seven fruits native to Brazil: graphs of scores and loadings.

bodily functions. $\mathrm{Mg}$ is present in the green parts of plants as a critical constituent of chlorophyll. $\mathrm{Mg}$ is present in high concentrations in vegetables. Our analysis determined that the mandacaru-de-três-quinas (1215.54 $\mu \mathrm{g} \cdot \mathrm{g}^{-1}$ ) showed higher $\mathrm{Mg}$ content compared with that of several fruits such as bilberries $\left(600 \mu \mathrm{g} \cdot \mathrm{g}^{-1}\right)$, lingonberries $\left(500 \mu \mathrm{g} \cdot \mathrm{g}^{-1}\right)$, cranberries $\left(700 \mu \mathrm{g} \cdot \mathrm{g}^{-1}\right)$, sea buckthorn $\left(600 \mu \mathrm{g} \cdot \mathrm{g}^{-1}\right)$, apples $\left(700 \mu \mathrm{g} \cdot \mathrm{g}^{-1}\right)$, peaches (900 $\left.\mu \mathrm{g} . \mathrm{g}^{-1}\right)$, and oranges (juice) $\left(900 \mu \mathrm{g} \cdot \mathrm{g}^{-1}\right)$, demonstrating similar values to those reported for blackcurrants $\left(1300 \mu \mathrm{g} \cdot \mathrm{g}^{-1}\right)$ and redcurrants $\left(1000 \mu \mathrm{g} \cdot \mathrm{g}^{-1}\right)$ and values lower than those reported for strawberries (1400 $\left.\mu \mathrm{g} . \mathrm{g}^{-1}\right)$ (Ekholm et al., 2007).

$\mathrm{Ba}$ is usually found in natural water in concentrations that vary between 0.0007 and $0.9 \mathrm{mg} \cdot \mathrm{L}^{-1}$. The health effects associated with exposure to the different compounds of $\mathrm{Ba}$ depend on the solubility of the compounds in the water or in the stomach. Water soluble compounds can produce harmful health effects (Agency for Toxic Substances and Disease Registry, 2007), causing hypokalemia. The lethal dose for humans is 3 to $4 \mathrm{~g}$, depending on both gender and body mass (Agency for Toxic Substances and Disease Registry, 1992). The WHO (World Health Organization, 2001) stipulates that $20 \mu \mathrm{g}$ of Ba/ $\mathrm{kg}$ of body mass can be a tolerable daily intake. Based on this limit, all the analyzed fruits, including the mandacaru-de-trêsquinas, were determined to have values within the limit set. Altundag \& Tuzen (2011) found values of barium in Turkey fruits (0.45-1.68 $\left.\mu \mathrm{g} \cdot \mathrm{g}^{-1}\right)$ lower than that of the majority of the fruits analyzed in the present study.

Among the fruits evaluated, the highest values of $\mathrm{Ca}$ (represented by principal component 6), $\mathrm{Cu}$, and $\mathrm{K}$ were found in the araticum-do-mato, with concentrations of $\mathrm{Pb}$ and $\mathrm{Cd}$ similar to those determined for guabiroba and pindo palm, respectively (Table 4). $\mathrm{Cu}$ is vital to many biological systems, 
affecting at least a part of 13 different enzymes. Considered essential in low concentrations, $\mathrm{Cu}$ can be accumulated in plants through soil contamination (Palmieri et al., 2005).

Ross (1994) reported that $\mathrm{Cu}$ is considered phytotoxic for concentrations exceeding $15 \mu \mathrm{g} \cdot \mathrm{g}^{-1}$, independent of the maturity stage. The araticum-do-mato samples exhibited $\mathrm{Cu}$ levels 5 times higher than the maximum allowable limit. Sattar et al. (1989) determined the $\mathrm{Cu}$ content in spices, fruits, and nuts (3.90-25.0 $\left.\mu \mathrm{g} . \mathrm{g}^{-1}\right)$, and Radwan \& Salama (2006) (1.22-18.3 $\left.\mu \mathrm{g} . \mathrm{g}^{-1}\right)$ determined that the $\mathrm{Cu}$ content in 330 samples of Egyptian fruits and vegetables had values higher than $15 \mu \mathrm{g} \cdot \mathrm{g}^{-1}$. In the literature, acceptable levels of $\mathrm{Cu}$ in fruit range from $0.43-2.74 \mu \mathrm{g} \cdot \mathrm{g}^{-1}$ (Altundag \& Tuzen, 2011) and 1.68-4.52 $\mathrm{Mg}_{\mathrm{g}} \mathrm{g}^{-1}$ (Duran et al., 2008), as well as 0.92 and $6.49 \mu \mathrm{g} \cdot \mathrm{g}^{-1}$ (Saracoglu et al., 2009).

Occurring in soil, food and bones, $\mathrm{Sr}$ is not considered to be an essential element (Meunier et al., 2004). Sr has similar chemical properties to those of $\mathrm{Ca}$, arousing interest in physiological bone growth studies in humans and animals (Marie, 2006). In fruits from Pakistan, Altundag and Tuzen (2011) found variations in the Sr content with values ranging from 0.8 to $2.53 \mu \mathrm{g} \cdot \mathrm{g}^{-1}$, which are quite lower than the values obtained in this study. In a study conducted on different types of teas, variations in the concentration of Sr of 6.23-411 $\mu \mathrm{g} \cdot \mathrm{g}^{-1}$ (Marie, 2006) were found.

As an essential element, $\mathrm{K}$, combined with sodium, regulates the functioning of the muscle system, including heartbeats. The araticum-do-mato had a $\mathrm{K}$ content similar to the values reported for apples (Malus domestica) (12500 $\left.\mu \mathrm{g} \cdot \mathrm{g}^{-1}\right)$, sugar apples (Annona squamosa L.) (11320 $\left.\mu \mathrm{g} \cdot \mathrm{g}^{-1}\right)$, and the Brazilian atemoya (Annona atemoya Mabb) $\left(10989 \mu \mathrm{g} \cdot \mathrm{g}^{-1}\right)$, a fruit from the same botanical genus of araticum-do-mato. These values of $\mathrm{k}$ exceed those reported for bilberries $\left(6800 \mu \mathrm{g} . \mathrm{g}^{-1}\right)$, lingonberries (5700 $\left.\mu \mathrm{g} \cdot \mathrm{g}^{-1}\right)$, cranberries $\left(7000 \mu \mathrm{g} \cdot \mathrm{g}^{-1}\right)$, sea buckthorn (9800 $\left.\mu \mathrm{g} \cdot \mathrm{g}^{-1}\right)$, rosehips $\left(1600 \mu \mathrm{g} \cdot \mathrm{g}^{-1}\right)$, and oranges (juice) $\left(900 \mu \mathrm{g} \cdot \mathrm{g}^{-1}\right)$. The reported levels found for strawberries $(15500$ $\left.\mu \mathrm{g} . \mathrm{g}^{-1}\right)$, blackcurrants $\left(18000 \mu \mathrm{g} \cdot \mathrm{g}^{-1}\right)$, redcurrants $\left(19100 \mu \mathrm{g} \cdot \mathrm{g}^{-}\right.$ $\left.{ }^{1}\right)$, raspberries $\left(13000 \mu \mathrm{g} \cdot \mathrm{g}^{-1}\right)$, and peaches $\left(18900 \mu \mathrm{g} \cdot \mathrm{g}^{-1}\right)$ (Ekholm et al., 2007) exceed the values found in this study.

Considered to be exclusively toxic, $\mathrm{Pb}$ is known to induce various dysfunctions in laboratory animals and humans by changing the antioxidant activities and by inhibiting the functional group HS in many enzymes (Kara, 2009). According to the World Health Organization (1996), the maximum limit of $\mathrm{Pb}$ allowed for food is $10 \mu \mathrm{g} \cdot \mathrm{g}^{-1}$. Comparing this limit to the values measured in this study, these fruits are considered acceptable, with lower $\mathrm{Pb}$ values than those reported in the literature at $0.48-2.14 \mu \mathrm{g} \cdot \mathrm{g}^{-1}$ (Altundag \& Tuzen, 2011), $1.91 \mu \mathrm{g} . \mathrm{g}^{-1}$ (Saracoglu et al., 2009), 6.6-9.2 $\mu \mathrm{g} . \mathrm{g}^{-1}$ (Sattar et al., 1989), and $1.66 \mu \mathrm{g} \cdot \mathrm{g}^{-1}$ (Zahoor et al., 2003). This metal is frequently found in high concentrations in plants grown near highways, as reported by Hamurcu et al. (2010) for apples (2.21 $\left.\mu \mathrm{g} . \mathrm{g}^{-1}\right)$, cornelians $\left(0.95-2.65 \mu \mathrm{g} \cdot \mathrm{g}^{-1}\right)$, and plums $\left(2.82 \mu \mathrm{g} \cdot \mathrm{g}^{-1}\right)$.

Known for multiple adverse effects on human health, both $\mathrm{Pb}$ and $\mathrm{Cd}$ are toxic agents associated with environmental contamination and industrial waste. Cadmium may accumulate in the human body, leading to renal dysfunction, bone diseases, and reproduction problems (Sobral et al., 2006). The levels observed in these fruits, mainly in pindo palm and the araticum-do-mato, were considered acceptable according to the WHO and FAO criteria: maximum limits of $\mathrm{Cd}$ in cereals and legumes is $0.5 \mu \mathrm{g} \cdot \mathrm{g}^{-1}$ (Klassen \& Watkins, 2001). The German and European Pharmacopoeias have established a maximum level of Cd of $0.1 \mu \mathrm{g} \cdot \mathrm{g}^{-1}$ for plants, including leaves, fruits, and roots. Contamination by $\mathrm{Cd}$ is dependent on the plant species and the growing conditions, with possible aggravations due to irrigation with contaminated water and/or use of fertilizers and herbicides during the cultivation process (Jansson, 2002). Compared with the values found in the present study, Hamurcu et al. (2010) determined that the Cd levels of fruit grown near highways are higher compared with the reported values for apples $\left(0.16 \mu \mathrm{g} \cdot \mathrm{g}^{-1}\right)$, cornelians $\left(0,07-0,017 \mu \mathrm{g} \cdot \mathrm{g}^{-1}\right)$, plums $\left(0.14 \mu \mathrm{g} \cdot \mathrm{g}^{-1}\right)$, and rosas $\left(0.06-0.16 \mu \mathrm{g} \cdot \mathrm{g}^{-1}\right)$.

The cadmium content in fruits has been reported to be 0.65-1.34 $\mu \mathrm{g} \cdot \mathrm{g}^{-1}$ (Sattar et al., 1989), 0.09-0.21 $\mu \mathrm{g} \cdot \mathrm{g}^{-1}$ (Zahoor et al., 2003), 0.16-0.24 $\mu g . g^{-1}$ (Abou-Arab et al., 1999),

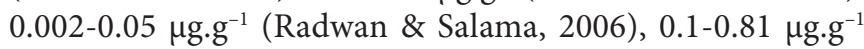
(Duran et al., 2008) and 0.02-0.72 $\mu$ g.g $\mathrm{g}^{-1}$ (Saracoglu et al., 2009).

As previously mentioned, Ca was the predominant mineral in the pindo palm, guabiroba, and uvaia fruit group. The values found in these three fruits were statistically lower than those found in the araticum-do-mato samples (Table 4). Ca is an essential mineral in the formation and maintenance of bones and teeth. This mineral is also involved in the transport of cellular membranes, the activation or release of enzymes, muscle contractions, and the transmission of nerve impulses (regulating the heartbeat) (Yebra \& Cancela, 2005). The Ca values found in the fruits in this study were lower than the values reported values for strawberries $\left(2000 \mu \mathrm{g} . \mathrm{g}^{-1}\right)$ blackcurrants $\left(2200 \mu \mathrm{g} \cdot \mathrm{g}^{-1}\right)$, raspberries $\left(1600 \mu \mathrm{g} \cdot \mathrm{g}^{-1}\right)$, bilberries $\left(1400 \mu \mathrm{g} \cdot \mathrm{g}^{-1}\right)$, lingonberries $\left(1000 \mu \mathrm{g} . \mathrm{g}^{-1}\right)$, cranberries $\left(1100 \mu \mathrm{g} \cdot \mathrm{g}^{-1}\right)$, apples $\left(500 \mu \mathrm{g} \cdot \mathrm{g}^{-1}\right)$, sea buckthorn $\left(500 \mu \mathrm{g} \cdot \mathrm{g}^{-1}\right)$, and peaches $\left(600 \mu \mathrm{g} \cdot \mathrm{g}^{-}\right.$ $\left.{ }^{1}\right)$. Both redcurrants $\left(2900 \mu \mathrm{g} \cdot \mathrm{g}^{-1}\right)$ and rosehips $\left(7000 \mu \mathrm{g} \cdot \mathrm{g}^{-1}\right)$ (Ekholm et al., 2007) had higher levels of this mineral compared with those of the fruit samples examined in the present study.

\section{Conclusions}

The fruits analyzed did not contain mineral concentrations exceeding the recommended values, except for the $\mathrm{Cu}$ content found in the araticum-do-mato samples. In addition to the macroelements $\mathrm{Ca}$ and $\mathrm{K}$ (recognized as basic minerals), the araticum-do-mato fruit samples also had high concentrations of trace elements such as $\mathrm{Pb}$ and $\mathrm{Sr}$, which could possibly be contaminants. Mandacaru-de-três-quinas had a predominance of $\mathrm{Ba}, \mathrm{Bi}$, and $\mathrm{Ga}$, which most likely are contaminants, as well as the essential macro- and micro-elements, $\mathrm{Mg}$ and $\mathrm{Mn}$. Among the fruit samples, uvaia and guabiroba had the highest levels of Al, a toxic metal, as well as the widely studied essential microelement Cr. In addition, uvaia had high levels of Fe and Zn, two essential microelements. Pindo palm had high amounts of two elemental contaminants, Cd and Ni. Yellow guava had high concentrations of $\mathrm{Na}$, while red guava contained high levels of Co. In general, the fruit samples had concentrations of the 
essential elements above or similar to the values reported for traditional fruits.

\section{Acknowledgements}

The authors would like to express our appreciation to the Brazilian Research Agency (Coordenação de Aperfeiçoamento de Pessoal de Nível Superior - CAPES) for their financial support.

\section{References}

Institute of Medicine. (2005). Dietary reference intakes for energy, carbohydrate, fiber, fat, fatty acids, cholesterol, protein, and amino acids. Washington: The National Academies Press. Retrieved from http://www.nap.edu/openbook.php?isbn=0309085373

Aberoumand, A., \& Deokule, S. S. (2009). Determination of elements profile of some wild edible plants. Food Analytical Methods, 2(2), 116-119. http://dx.doi.org/10.1007/s12161-0089038-Z

Abou-Arab, A. A. K., Kawther, M. S., El Tantawy, M. E., Badeaa, R. I., \& Khayria, N. (1999). Quantity estimation of some contaminants in commonly used medicinal plants in the Egyptian market. Food Chemistry, 67(4), 357-363. http://dx.doi.org/10.1016/S03088146(99)00082-5

Agency for Toxic Substances and Disease Registry - ATSDR. (1992). Toxicological profile for Barium. Atlanta. Atlanta: ATSDR. Retrieved from http://www.atsdr.cdc.gov/ToxProfiles/tp.asp?id=327\&tid=57

Agency for Toxic Substances and Disease Registry - ATSDR. (2001). Toxicological profile for Cobalt. Atlanta: ATSDR. Retrieved from http://www.atsdr.cdc.gov/toxprofiles/tp7

Agency for Toxic Substances and Disease Registry - ATSDR. (2008). Toxicological profile for Manganese. Atlanta: ATSDR.

Agency for Toxic Substances and Disease Registry - ATSDR. (2007). Toxicological profile for Barium and Barium compounds. Atlanta: ATSDR. Retrieved from http://www.atsdr.cdc.gov/toxprofiles/ tp7.pdf

Altundag, H., \& Tuzen, M. (2011). Comparison of dry, wet and microwave digestion methods for the multi element determination in some dried fruit samples by ICP-OES. Food and Chemical Toxicology, 49(11), 2800-2807. PMid:21843582. http://dx.doi. org/10.1016/j.fct.2011.07.064

Bertini, I., Sigel, A., \& Sigel, H. (2001). Handbook on Metalloproteins. New York: MarcelDekker.

Brack, P., Kinupp, V. F., \& Sobral, M. E. G. (2007). Levantamento preliminar de espécies frutíferas de árvores e arbustos nativos com uso atual ou potencial do Rio Grande do Sul. Revista Brasileira de Agroecologia, 2(1), 1769-1772,

Cassaret, A., \& Doull's, D. (1996). Casarett and Doull's toxicology: the basic science of poisons. (5th ed.). USA: McMillan Publishing.

Duran, A., Tuzen, M., \& Soylak, M. (2008). Trace element levels in some dried fruit samples from Turkey. International Journal of Food Sciences and Nutrition, 59(7-8), 581-589. PMid:18991103. http:// dx.doi.org/10.1080/13561820701507910

Ekholm, P., Reinivuo, H., Mattila, P., Pakkala, H., Koponen, J., Happonen, A., Hellström, J., \& Ovaskainen, M. L. (2007). Changes in the mineral and trace element contents of cereals, fruits and vegetables in Finland. Journal of Food Composition and Analysis, 20(6), 487-495 http://dx.doi.org/10.1016/j.jfca.2007.02.007
Haider, S., Naithani, V., Barthwal, J., \& Kakkar, P. (2004). Heavy metal content in some therapeutically important medicinal plants. Bulletin of Environmental Contamination and Toxicology, 72(1), 119-127. PMid:15058663. http://dx.doi.org/10.1007/s00128-003-0249-0

Hamurcu, M., Ozcan, M. M., Dursun, N., \& Gezgin, S. (2010). Mineral and heavy metal levels of some fruits grown at the roadsides. Food and Chemical Toxicology, 48(6), 1767-1770. PMid:20346997. http:// dx.doi.org/10.1016/j.fct.2010.03.031

Jansson, G. (2002). Cadmium in arable crops: the influence of soil factors and liming. (Doctoral thesis). Swedish University of Agricultural Sciences, Uppsala.

Kara, D. (2009). Evaluation of trace metal concentrations in some herbs and herbal teas by principal component analysis. Food Chemistry, 114(1), 347-354. http://dx.doi.org/10.1016/j. foodchem.2008.09.054

Kinnup, V. F., \& Barros, I. B. I. (2008). Teores de proteína e minerais de espécies nativas, potenciais hortaliças e frutas. Ciência e Tecnologia de Alimentos, 28(4), 846-857. http://dx.doi.org/10.1590/S010120612008000400013

Klassen, C. D., \& Watkins, J. B. (2001). Toxicologia, a ciência básica dos tóxicos. Lisboa: McGraw-Hill.

Lorenzi, L., Bacher, L., Lacerda, L., \& Sartori, S. (2006). Frutas brasileiras e exóticas cultivadas (de consumo in natura). São Paulo: Instituto Plantarum de Estudos da Flora.

Marie, P. J. (2006). Strontium ranelate: a physiological approach for optimizing bone formation and resorption. Bone, 38(2), S10-S14. PMid:16439191. http://dx.doi.org/10.1016/j.bone.2005.07.029

Meunier, P. J., Roux, C., Seeman, E., Ortolani, S., Badurski, J. E., Tim D., Spector, T. D., Cannata, J., Balogh, A., Lemmel, E. M., PorsNielsen, S., Rizzoli, R., Genant, H. K., \& Reginster, J. Y. (2004). The effects of strontium ranelate on the risk of vertebral fracture in women with postmenopausal osteoporosis. The New England Journal of Medicine, 350, 459-468. PMid:14749454. http://dx.doi. org/10.1056/NEJMoa022436

Odhav, B., Beekrum, S., Akula, U. S., \& Baijnath, H. J. (2007). Preliminary assessment of nutritional value of traditional leafy vegetables in KwaZulu-Natal, South Africa. Journal of Food Composition and Analysis, 20(5), 430-435. http://dx.doi. org/10.1016/j.jfca.2006.04.015

Özcan, M. M., \& Hacıseferoğulları, H. (2007). The strawberry (Arbutus unedo L.) fruits: chemical composition, physical properties and mineral contents. Journal of Food Engineering, 78(3),1022-1028. http://dx.doi.org/10.1016/j.jfoodeng.2005.12.014

Padovani, R. M., Amaya-Farfán, J., Colugnati, F. A. B., \& Domene, S. M. A. (2006). Dietary reference intakes: aplicabilidade das tabelas em estudos nutricionais. Revista de Nutrição, 19(6), 741-760. http:// dx.doi.org/10.1590/S1415-52732006000600010

Palmieri, R. M., La Pera, L., Di Bella, G., \& Dugo, G. (2005). Simultaneous determination of $\mathrm{Cd}(\mathrm{II}), \mathrm{Cu}(\mathrm{II}), \mathrm{Pb}(\mathrm{II})$ and $\mathrm{Zn}(\mathrm{II})$ by derivative stripping chronopotentiometry in Pittosporum tobira leaves: a measurement of local atmospheric pollution in Messina (Sicily, Italy). Chemosphere, 59(8), 1161-1168. PMid:15833490. http://dx.doi.org/10.1016/j.chemosphere.2004.11.066

Pereira, M. C., Stefens, R. S., Jablonski, A., Hertz, P. F., Rios, A. O., Vizzotto, M., \& Flôres, S. H. J. (2012). Characterization and antioxidant potential of brazilian fruits from the Myrtaceae family. Journal of Agricultural and Food Chemistry, 60(12), 3061-3067. PMid:22397467. http://dx.doi.org/10.1021/jf205263f

Radwan, M. A., \& Salama, A. K. (2006). Market basket survey for some heavy metals in Egyptian fruits and vegetables. Food and 
Chemical Toxicology, 44(8), 1273-1278. PMid:16600459. http:// dx.doi.org/10.1016/j.fct.2006.02.004

Ross, S. M. (1994). Toxic Metals in Soil-Plant Systems. (1th ed., pp. 496). New York: John Wiley \& Sons.

Saracoglu, S., Tuzen, M., \& Soylak, M. (2009). Evaluation of trace element contents of dried apricot samples from Turkey. Journal of Hazardous Materials, 167(13), 647-652. PMid:19195780. http:// dx.doi.org/10.1016/j.jhazmat.2009.01.011

Sattar, A., Wahid, M., \& Durrani, S. K. (1989). Concentration of selected heavy metals in spices, dry fruits and plant nuts. Plant Foods for Human Nutrition, 39(3), 279-286. PMid:2608637. http://dx.doi. org/10.1007/BF01091938

Sobral, M., Jarenkow, J. A., Brack, P., Irgang, B., Larocca, J., \& Rodrigues, R. S. (2006). Flora arbórea e arborescente do Rio Grande do Sul, Brasil. São Carlos: RiMa.
World Health Organization - WHO, Compounds International Programme on Chemical Safety - IPCS. (2001). Barium and Barium. Consise international Chemical Assessment Document 33. Geneva.

World Health Organization - WHO. (1996). Trace elements in human nutrition and health. Geneva: WHO.

Yebra, M. C., \& Cancela, S. (2005). Continuous ultrasound-assisted extraction of cadmium from legumes and dried fruit samples coupled with on-line preconcentration-flame atomic absorption spectrometry. Analytical and Bioanalytical Chemistry, 382(4), 10931098. PMid:15909187.http://dx.doi.org/10.1007/s00216-005-3237-x

Zahoor, A., Jaffar, M., \& Saqib, M. (2003). Elemental distribution in summer fruits of Pakistan. Nutrition \& Food Science, 33(5), 203-207. http://dx.doi.org/10.1108/00346650310499712 